（日本化学会誌，1975，（1）, p. 171～173）

\title{
$S, S^{\prime}$-ジフェニルジチオカルボナートの光化学反応機構
}

\author{
（1974 年 2 月 15 日 受理）
}

小瀬垣 公穂 - 近 藤 修 寿・津 田 和 -*

\begin{abstract}
$S, S^{\prime}$-ジフェニルジチオカルボナート〔1]は光分解によってベンゼンチイルラジカルのみを生成し, このチイルラジカルによって重合が開始されるが, その動力学的結果は通常のラジカル重合と異なって いるので，その重合反応機構を解明するためシクロへキセンとの反応を行ない，反応生成物からその重 合機構について考察した。このさい, 従来見いだされていなかったチオフェノールが反応系に存在する ことを見いだすとともに，このチオフェノールが停止反応あるいは連鎖移動反応に関与することによ り，〔1〕による光重合機構を反応論的に明らかにした。
\end{abstract}

\section{1 緒言}

有機硫黄化合物の光分解では容易にチイルラジカルが生成し， それがラジカル重合を開始することはよく知られている1)。津田 ・大津も ${ }^{2)}$ ジベンゾイルジスルフィドが光化学的に容易にラジカ ル分解して, ベンゾイルチイルラジカルを生成し, ラジカル重合 の開始剤となることを見いだした。

他方, チイルラジカルの反応性については数多くの報告がされ ているが，それらの多くはチイルラジカルの発生に他のラジカル

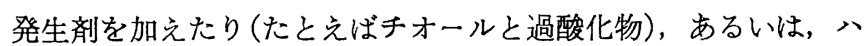
ロゲン原子ないしはハロゲン化合物存在下に反応を行なってい る。その結果, 反応系が複雑となり, チイルラジカルの反応性を 直接検討することをむずかしくしている。

1969 年, Heine と Metzner ${ }^{3)}$ は, $p, p^{\prime}$ 二置換 $S, S^{\prime}$-ジアリー ルジチオカルボナートが容易に光分解して, ジアリールジスルフ ィドを生成することから，チイルラジカルが反応中間体であると 報告している。この結果から， $S, S^{\prime}$-ジフェニルジチオカルボナ 一ト[1]を光化学的に分解すれば, ベンゼンチイルラジカル 〔11〕のみが反応中間体として生成し，チイルラジカルの反応性 を倹討するのに最適の系であると考兄られる。そこで〔1]によ るラジカル重合の動力学を検討したところ4)，〔1〕の光分解によ って生じた [11]がラジカル重合を開始するとともに，[1]はジ ベンゾイルジスルフィドの場合と同様に ${ }^{2)}$ ，連鎖移動剂あるいは 停止剤としても作用することを見いだした。しかしながらジベン ゾイルジスルフィドを用いた重合反応に括ける連鎖移動はポリマ ーラジカルのジスルフィド結合への攻撃とされているが, [1]で はそのような型の反応は考学られない。

* 名古屋工業大学, 466 名古屋市昭和区御器所町

1) R. J. Kern, J. Amer. Chem. Soc., 77, 1382(1955); T. E. Ferington, A. V. Tobolsky, ibid., 77, 4510(1955); T. Otsu, J. Polym. Sci., 21, 559(1956); T. Otsu, K. Nayatani, I. Muto, M. Imai, Makromol. Chem., 27, 142(1958).

2) K. Tsuda, T. Otsu, Bull. Chem. Soc. Jap., 39, 2206(1966).

3) H. G. Heine, W. Metzner, Ann. Chem., 724, 223(1969).

4) K. Tsuda, K. Kosegaki, Makromol. Chem., 161, 267 (1972).
一方, ジフェニルジスルフィドの光分解によって生成するチイ ルラジカルは，4-ビニルシクロへキセンの 3-位の水素を引き抜 かず，もっばら二重結合へ付加するといら報告もあるず。また他 方, チオール類の重合反応に怙よぼす影響についても多くの研究 がある。そこで [1]の光分解によって生じる[11] の反応性を 検討すれば, チイルラジカルによる重合反応の特徴とされている 開始反応とともに連鎖移動あるいは停止反応が同時に起こる点に ついて明らかにしらるものと期待される。そこで [1]とシクロ へキセン [9] との光反応を行ない, [1]から生成する [11]の [9] 飞対する付加反応（すなわち開始反応）, 置換反応，水素引 き抜き反応（連鎖移動反応）叔よび二量化反応などの反応性の検 討を行なった。

\section{2 実験}

\section{$2.1 S, S^{\prime}$-ジフェニルジチオカルボナートの合成}

チオフェノールを水酸化ナトリウム水溶液へ加え, ついで $5^{\circ} \mathrm{C}$ 以下にたもち，かきまぜながらホスゲンのトルエン溶夜を $3 \sim 4$ 時間かけて滴下し, その後 $30 \sim 40^{\circ} \mathrm{C}$ に加熱して未反応のホスゲ ンを追い出す。反応液を水洗し乾燥後トルエンを留去する。析出 した白色固体をエタノールで再結晶する。収率 $30 \%, \mathrm{mp} \mathrm{40.8〜}$ $41.9^{\circ} \mathrm{C}$ (文献值 ${ }^{3)} 41 \sim 42^{\circ} \mathrm{C}$ ), $\lambda_{\max } 227 \mathrm{~nm}(\log \varepsilon 4.12), \lambda_{\max } 260$ $\mathrm{nm}(\log \varepsilon 3.82)$ (エタノール中)。

$2.2 S, S^{\prime}$-ジフェニルジチオカルボナートとシクロヘキセン との反応

$S, S^{\prime}$-ジフェニルジチオカルボナート $2.96 \mathrm{~g}\left(1.20 \times 10^{-2} \mathrm{~mol}\right)$ とシクロヘキセン $60 \mathrm{ml}$ をシクロヘキサン $260 \mathrm{ml}$ に溶かし, 窒 素気流下, 内部照射型 $100 \mathrm{~W}$ 高圧水銀灯（理工科学社製）で 72 時 間照射した。少量の反応のさいは，パイレックス封管を用い，外 部照射型水銀灯を用いて光照射を行なった。

\section{3 生成物の分析}

反応混合物から室温減圧下で溶媒を留去し, 生成物はガスクロ マトグラフィーで分離し，IR, NMR, およびガスクロマトグラフ 1ーの保持時間で標品と此較同定した。

5) J. R. Schelton, A. E. Champ, J. Org. Chem., 30, 4183 (1965). 


\section{4 標品の合成}

2.4.1 フェニルチオシクロヘキサン: チオフェノールとシク ロヘキセンをシクロへキサン溶媒で， $80^{\circ} \mathrm{C} ， 5$ 時間加熱し，ガス クロマトグラフィーで分離精製した。

2.4 .23 3-フェニルチオシクロへキセン [3] : シクロへキセン 飞暗所, 氷冷下, 塩素を吹き込み，3ークロロシクローキセンを合 成した。bp $44 \sim 47.5^{\circ} \mathrm{C} / 22 \mathrm{mmHg}$ (文献値) $59^{\circ} \mathrm{C} / 29 \mathrm{mmHg}$ )。つ いでこれをエタノール中チオフェノールのナトリウム塩と反応さ せ [3]を得た。

2.4.3 3，3'-ビシクロへキセニル：文献?にしたがい, エチルマ グネシウムブロミドと 3-クロロシクロへキセンから合成した。

2.4.4 シクロへキセン, シクロヘキサン: 常法により精製し, 反応前再蒸留を行なって用いた。

\section{5 生成物の定量}

ガスクロマトグラフィーの内部標準法で行なった (Silicone SE $30,20 \%$, Carbowax $20 \mathrm{M}, 10 \%$, 各 $4 \mathrm{~mm} \times 1 \mathrm{~m}$ )。

\section{3 結 果と考察}

[1]と [9]の光反応終了後, 反応生成物の分離, 同定を行な った。その結果を（1）式に示す。ここで，この反応は，パイレ ックスの光透過度と〔1]の吸収波長を考慮すると, [1]のカル ボニル基の励起によって反応が開始すると考えられる。

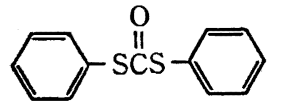

[1]

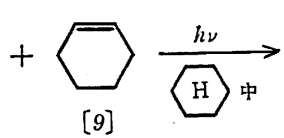

[9]

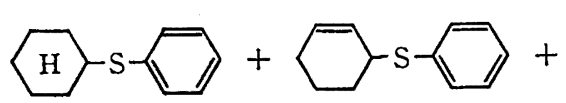

[2]

[3]

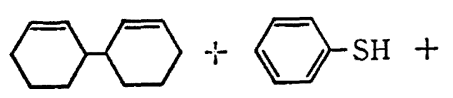

[5]

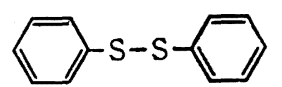

[6]

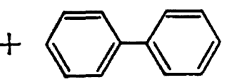

[7]
主生成物は $[11] の[9]$ へ付加した $[2]$ と [9]の 3-位へ置 換した [3]である。少量得られる生成物はビシクロへキセニ ル[4], チオフェノール[5], ジフェニルジスルフィド[6]と 徽量のビフェニル[7]である。二つの[11]が［9]飞付加し た 1,2-ビス(フェニルチオ)シクローキサンは得られなかった。 またその他住量ではあるが未確認生成物が存在する。

つぎに反応生成物の二次的反応について明らかにするため, [1]の光分解反応の経時変化をみたのが図 1 である。

付加反応汇よる[2]の生成量がもっとも多く, ついで置換反 応による[3]の生成である。また生成物 [4]と[6]の量は反 応中注とんど一定であるが [5]の量は反応の進行とともに少し 減少する。このことは [5]は生成しても, 二次的反応によって 消費されることを示している。生成物と反応の経時変化から反応 はつぎの式（2）で進んでいると考觉られる。

6) M. L. Poutsma, J. Amer. Chem. Soc., 87, 2162(1965).

7) A. Berlande, Compt. Rend., 213, 484(1941).

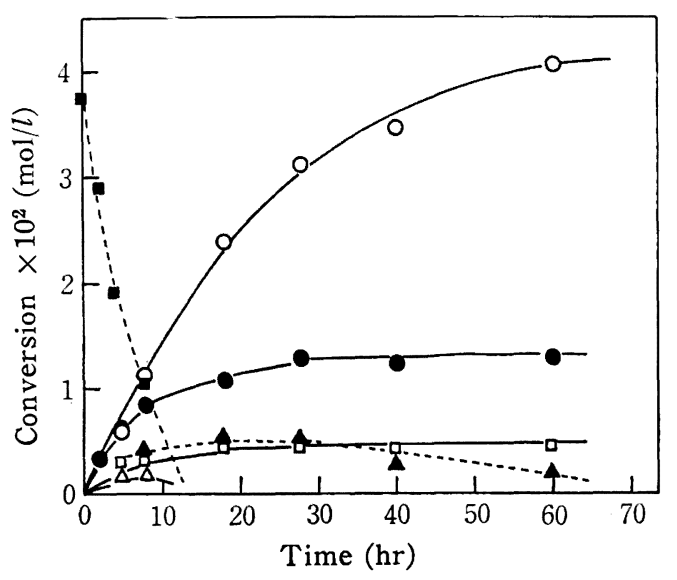

Fig. 1 Conversion of diphenyl dithiocarbonate and the amounts of reaction products with reaction time

-- - : Diphenyl dithiocarbonate

-O- : Phenylthio cyclohexane

- - : 3-Phenylthio cyclohexene

$-\square-$ : Bicyclohexenyl

--A-- : Thiophenol

$-\triangle-$ : Diphenyl disulfide

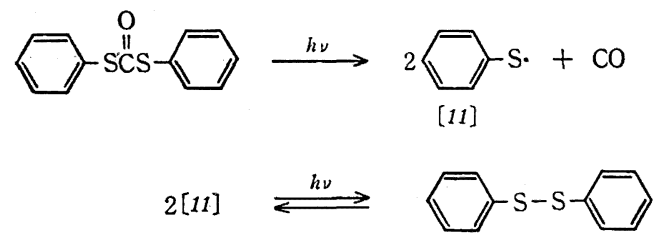

[6]

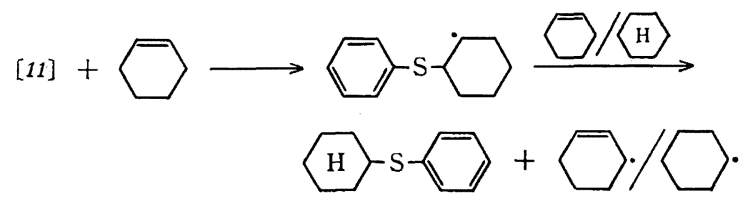

[2]

[11]

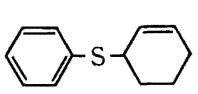

[3]

[11]<smiles>[C]1CCCCC1</smiles>

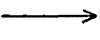

[2]

[11]<smiles>C1=CCCCC1</smiles>
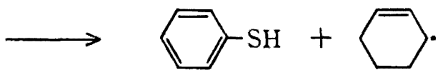

[5]<smiles>C1=CCCCC1</smiles>

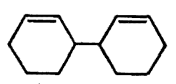

[4]

$[\overline{5}]$

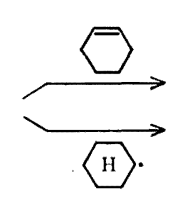

[2]

$[11]+\mathrm{H}$

まず，〔1〕が光照射によって励起され Norrish I 型のように， カルボニル炭素と硫黄の結合が切断されて，[11〕と一酸化炭素 になる。生じた一酸化炭素はただちに系外に出，[11]のみが[9] との反応を行なら。付加体 [8]は[9]から水素を引き抜き[2] となる。また [11]は[9]の3-位から水素を引き抜き〔5]と シクロヘキセニルラジカルを生成する。このシクロへキセニルラ 
ジカルは [11]との反応の他に，二量化により〔4]を生成する。 また〔5]はこの条件下 [9] へ付加し[2]を生成する。この反 応から〔1]が消費されたのちも〔2]の量が増加し，〔5]の量 は減少する(図 1 )。[6]は [11]の二量化によって生成するが, この反応がかご内で起こったか，かご外で起こったかについては 現在のところ明らかではない。生成した［6]の一部はふたたび 分解して〔11]となる。

以上の結果をSchelton ら5の結果と比較するのは興味がある。 彼らは [6]と 4-ビニルシクロヘキセン [10]の光反応を行ない, [11]と〔10]の付加体を 38\%，置換体を $16.7 \%$ で得ている ((3) 式)。

[6]

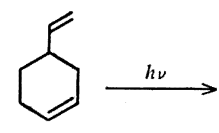

[10]<smiles>C1=CCC(Cc2ccccc2)CC1</smiles>

$38 \%$ 付加体

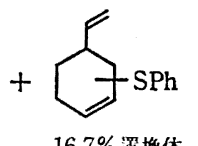

$16.7 \%$ 㳑换体

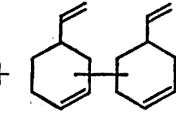

少量
[1]の反応では, 付加と置換の比（[2]と〔3]の比）は反応 時間とともに変化しているが，彼らは反応時間を延長しても生成 物比は変わらないと述べていることから, 平衡に達したのちの収 率と考えられる。そこで図 1 から，ほぼ平衡に達したと思われる 60 時間後の值で比較すると付加が $55.1 \%$ ，置換が $16.3 \%$ とな り, 両者の比は $77.2: 22.8$ である。このさい問題となるのは ［5]であるが，［5]と［9]の反応は図 2 に示したように進行 している。

図 1 で〔5]の量がそれほど多くないのは，一つには反応混合 物からの[5]の分離, 定量が実験操作上の問題から正確に行な えないこと，もら一つは生成した［5]の二次反応によると考光 られる。ここで見かけ上，[2]の生成量が［5]の減少量と一致 しないが，図 2 から明らかなように，[5]と〔9]の反応は比較 的技そく，[2]の増加は生成した〔5]によることが間接的に認 められる。同様の結果は，[6]と[10]の反応でも見られるはず である。Schelton らの[5]は生成していないとの結果は，[5] がいったん生成して，二次反応を起こしたあとのため，捕捉でき なかったことによると思われる。

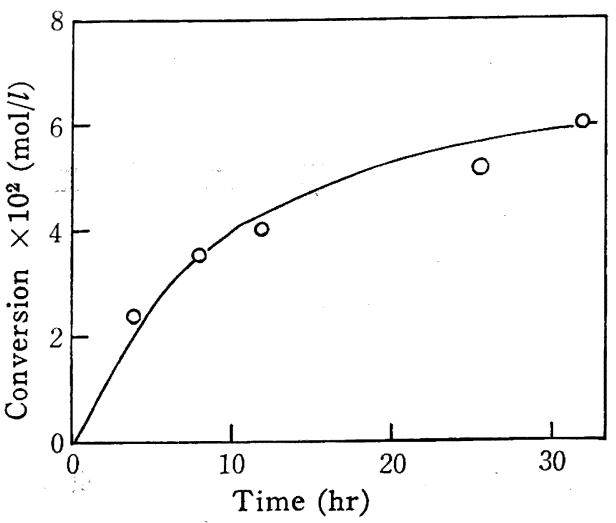

Fig. 2 The amount of [2] by the photochemical reaction of thiophenol with cyclohexene

$[\mathrm{PhSH}]=7.44 \times 10^{-2} \mathrm{~mol} / \mathrm{l}$

また，[6]と [9]の光反応を同条件で行ならと，付加体 [2] と置換体 [3]の比は 76.3:23.7 であった（（4）式)。この生成

$[6]+[9] \underset{\mathrm{H} 中}{\stackrel{h \nu}{\longrightarrow}}$

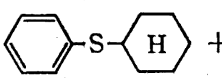

$76.3 \%$

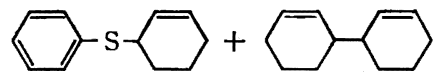

$23.7 \%$
微量
物比は, [1]と[9]の反応に特ける比とほほ等しく，また Schelton らの結果とも類似している。しかし上に述べたように， この值は二次的反応を含んでいるものであり，両者の此を正しく 表わしているのは反応の初期状態の比である。そこで図 1 の付加 体と置換体の初期の量を見ると，両者はほとんど変わらず，置換 反応すなわち水素引き抜き反応が，付加反応と同じぐらい起こり やすいことがわかる。このように水素引き抜きによって〔5]が 生成しやすいこと，拈よび〔5]からふたたび氷素が引き抜かれ やすいことは, 以前のジベンゾイルジスルフィド2)あるいは[1 $]^{4)}$ による重合に拈いて硫黄化合物の量の増加にともなって連鎖移動 が増加することをよく説明する。また，以上の点から，チイルラ ジカルによる重合では生長反応以外に，連鎖移動，停止反応が起 こり，それが重合速度を開始剤濃度の $1 / 2$ 次に比例させない結果 をもたらすことは明らかである。

\section{Mechanism of Photochemical Reaction of $\boldsymbol{S}, \boldsymbol{S}^{\prime}$-Diphenyl Dithiocarbonate Initiator}

Kimio Kosegaki, Shuji Kondo and Kazuichi Tsuda

Nagoya Institute Technology ; Gokisocho, Showa-ku, Nagoya-shi 466 Japan

Since $S, S^{\prime}$-diphenyl dithiocarbonate [ 1$]$ which initiated the photochemical polymerization easily decomposed into benzene thiyl radical, [1] was allowed to react with cyclohexene to clarify the reaction mechanism.

Photochemical reaction of [1] proceeded by the scission of carbonyl-sulfur bond and the produced benzene thiyl radical reacted with cyclohexene. From the reaction products, the reaction mechanism was clarified. In this case, thiophenol which was believed to be absent in the reaction products was found in the reaction mixture.

The initiation and termination mechanisms of the photochemical polymerization by benzene thiyl radical were thus clarified from the reaction products of [1] with cyclohexene. 